\title{
CURRÍCULO, CONHECIMENTOS E MÍDIAS: TÁTICAS E INVENÇÕES DOS SUJEITOS NOS COTIDIANOS DO ENSINO MÉDIO
}

- EDIVAN CARNEIRO DE ALMEIDA

Universidade Estadual de Feira de Santana

ELENISE CRISTINA PIRES DE ANDRADE

Universidade Estadual de Feira de Santana

Este trabalho busca estabelecer possiveis diálogos sobre as práticas dos sujeitos nos cotidianos do Ensino Médio, partindo dos resultados da pesquisa de mestrado, com experiências vividas-narradas por estudantes, no Projeto Comunicação, Interação e Aprendizagem, desenvolvido em uma escola pública do sertão baiano. Percorrendo traços-fragmentos dessas experiências e experimentando expressões, buscamos compreender algumas possibilidades de realização de práticas de construção-expressão de conhecimentos e invenção de currículos, operadas nos/dos/com os cotidianos escolares. Percebemos que as experiências narradas, por meio de vídeos, configuram oportunidades significativas de construção de conhecimentos e de usos-apropriações de gêneros textuais, artefatos e mídias-linguagens, através da produção de imagens, informações e textos, orais e escritos, veiculados nos cotidianos da escola e na comunidade externa, através da rádio-escola, do blog e do boletim impresso. As vídeo-narrativas dessas experiências também nos possibilitaram a compreensão de que as atividades desenvolvidas no Projeto provocam uma fissura no currículo oficial-enrijecido-prescritivo e potencializam a criação de um currículo singular, in-ventando outros modos de ver-pensar-realizar experimentação/construção/ produção de conhecimentos-saberes-poderes, sentidos e subjetividades, dentrofora da sala de aula/escola. Currículo/conhecimento compartilhado, cheio de vida, alegre, animado e arejado pelos/com os significados produzidos pelos estudantes do Ensino Médio.

Palavras-chave: Cotidianos. Currículo. Conhecimento. Mídias. Linguagens. 
This study aims to establish possible dialogues on the practices of subjects in the everyday life of high school, starting from the results of the Masters survey, with experienced experiences-narrated by students in the communication, interaction and learning project, developed in a public school of the hinterland of Bahia. Through traces-fragments of these experiences and experiencing expressions, we seek to understand some possibilities to accomplish the construction of practices-expression of knowledge and invention of curriculums, operated in/of/with the everyday school. We have realised that the narrated experiences, through videos, set up significant opportunities to construct knowledge and usages - appropriations of textual genres, artifacts and media-languages was also possible, through the production of images, information and oral and written texts conveyed into everyday life of the school and into the external community, through the radio-school, the blog and the printed bulletin. The video-narratives of these experiences also enabled us to understand that the activities developed in the project has brought a significant change in the official curriculum which is prescriptive, thus it has been possible to potentiate the development of a singular curriculum, by creating other modes of viewing-thinking-conducting experimentation/construction/production of knowledge-knowing-powers, senses and Subjectivities, inside and outside of the classroom/ school. Curriculum/shared knowledge, full of life, cheerful, animated and airy by/with the meanings produced by high school students.

Keywords: Everyday life. Resume. Knowledge. Media. Languages.

\section{RESUMEN CURRÍCULO, CONOCIMIENTOS Y MEDIOS: TÁCTICAS Y INVENCIONES DE LOS SUJETOS EN LOS COTIDIANOS DE LA ENSEÑANZA MEDIA}

Este trabajo busca establecer posibles diálogos sobre las prácticas de los sujetos en los cotidianos de la Enseñanza Media, partiendo de los resultados de la investigación de maestría, con experiencias vividas-narradas por estudiantes en el Proyecto Comunicación, Interacción y Aprendizaje, desarrollado en una escuela pública del sertón baiano. Recorriendo trazos-fragmentos de esas experiencias y experimentando expresiones, buscamos comprender algunas posibilidades de realización de prácticas de construcción-expresión de 
conocimientos e invención de currículos, operadas en los/de los/ con los cotidianos escolares. Percibimos que las experiencias narradas, por medio de videos, configuran oportunidades significativas de construcción de conocimientos y de usos-apropiaciones de géneros textuales, artefactos y medios-lenguajes, a través de la producción de imágenes, informaciones y textos, orales y escritos, vehiculados en los cotidianos de la escuela y en la comunidad externa, a través de la radio-escuela, del blog y del boletín impreso. Las video-narrativas de esas experiencias también nos posibilitaron la comprensión de que las actividades desarrolladas en el Proyecto provocan una fisura en el currículo oficial-endurecido-prescriptivo y potencializa la creación de un currículo singular, in-ventando otros modos de ver-pensar-realizar experimentación/construcción/producción de conocimientos-saberes-poderes, sentidos y subjetividades, dentro del clase/escuela. Currículo/conocimiento compartido, lleno de vida, alegre, animado y aierado por los/con los significados producidos por los estudiantes de la Enseñanza Media.

Palabras claves: Cotidianos. Currículo. Conocimiento. Medios. Lenguajes.

A "fabricação" que se quer detectar é uma produção, uma poética - mas escondida, porque ela se dissemina nas regiões definidas e ocupadas pelo sistema da "produção" (televisiva, urbanística, comercial etc.) e porque a extensão sempre mais totalitária desse sistema não deixa aos "consumidores" um lugar onde possam marcar o que fazem com os produtos.

Michael de Certeau (2012, p. 38-39)

\section{A produção do currículo nos cotidianos de escolas públicas}

Escolher os estudos dos cotidianos como perspectiva para a compreensão do currículo escolar, especialmente a partir de alguns conceitos apresentados por Michael de Certeau (2012), em seu livro "A invenção do cotidiano: artes de fazer" e das tentativas de autores brasileiros que deles fazem usos ${ }^{1}$ e apropriações em bus-

1 Para Certeau (2012), os usos consistem em "maneiras de empregar", operação dos consumidores que subverte, por meio de apropriação e bricolagem, a pro- ca de compreender como os sujeitos escolares criam práticas singulares nos espaços em que atuam, nos coloca frente ao desafio de efetivar um exercício de pensamento que parte do meio (DELEUZE; GUATTARI, 1995), dos cotidianos escolares em que estamos implicados, das re-

dução espetacularizada, realizada pelos centros de poder (empresas, governos, meios de comunicação), cujos objetivos e estratégias buscam determinar uma realidade, construir o mundo. 
des de saberes-fazeres-poderes e conhecimentospensamentos ${ }^{2}$ que aí se tecem, entrelaçando-nos constantemente.

Partir do meio porque na rede não existem localizações fixas que possam servir de base/ território, de certeza, ponto (único) de partida, mas sim múltiplas interconexões que possibilitam fluxos em variadas direções, sem forma definida a priori. Com Deleuze e Guattari (1995, p. 15) tentar compreender, por outras perspectivas, o pensamento e a produção de conhecimento como rizoma, processados através dos princípios da conexão e da heterogeneidade: "qualquer ponto de um rizoma pode ser conectado a qualquer outro e deve sê-lo. É muito diferente da árvore ou da raiz, que fixam um ponto, uma ordem".

Assim, este trabalho é uma tentativa de discutir o currículo, percorrendo os fluxos/fios/ interconexões dessas redes/rizomas/relações, que se tecem entre os sujeitos, nos mais variados contextos, igualmente enredando os saberes-fazeres-poderes que os atravessam nos cotidianos escolares, considerando os agenciamentos, os processos de subjetivação que os afetam/envolvem, buscando produzir visibilidade sobre as invenções que tais sujeitos operam nesses espaçostempos. Nesse sentido, entendemos o sujeito como aquele "cuja racionalidade é sempre produzida socialmente" (VEIGA-NETO, 2002, p. 49), em processos de subjetivação que ocorrem nos cotidianos, nas redes de fazeres-poderes-conheceres que neles se tecem, concepção que parte dos estudos de Foucault (2004).

Posto isso, podemos nos questionar sobre como são vistos os cotidianos escolares e como

2 A utilização de palavras conjugadas em itálico, ao longo do texto, inspira-se em pesquisadores brasileiros nos/dos/com os cotidianos escolares, a exemplo de Nilda Alves e Inês Oliveira, da Universidade Estadual do Rio Janeiro, e Carlos Eduardo Ferraço, da Universidade Federal do Espírito Santo, para marcar a superação epistemológica e política de dicotomias/antagonismos presentes nas concepções modernas de ciência e filosofia do conhecimento. tais visualidades afetam a ação dos sujeitos nesses espaços, impactam o currículo escolar, compondo imagens que povoam nossas ações, pensamentos e reflexões a respeito das escolas públicas. Que imagens emergem em nós, ao nos depararmos com o termo cotidiano? Em se tratando dos cotidianos escolares, especialmente de escolas públicas, que imagens temos deles? Como essas imagens/visualidades têm sido produzidas em nós educadores, nos estudantes e na sociedade como um todo? Como os meios de comunicação, as produções científicas, os engendramentos gestados nas esferas públicas (tensionadas pela "iniciativa" privada) e suas estratégias de governabilidade, as macropolíticas de (re)definição do currículo e das práticas dos sujeitos, as tentativas de determinar os processos educativos, têm contribuído na produção desse imaginário sobre a educação pública? Imersos nos cotidianos de escolas públicas, quais as (im)possibilidades dos sujeitos inventarem e realizarem práticas educativas, singulares e significativas (com/ para os estudantes), de construção de conhecimentos e criação de currículos, implicados nos engendramentos e estratégias políticas hegemônicas?

Assim, com Certeau (2012), buscamos inverter a perspectiva hegemônica de observação e análise dos cotidianos escolares, do currículo e das práticas dos sujeitos que neles atuam, em que se destacam (e se generalizam) apenas os problemas vividos nesses espaçostempos, protagonizando estratégias para sua transformação, gestadas por instâncias superiores de governança da educação pública, externas aos referidos cotidianos e aos sujeitos que neles habitam. Procuramos dirigir nosso olhar para outra produção, observando que, frente a uma:

[...] produção racionalizada, expansionista além de centralizada, barulhenta e espetacular, corresponde outra produção, qualificada de 'consumo': esta é astuciosa, é dispersa, mas 
ao mesmo tempo ela se insinua ubiquamente, silenciosa e quase invisivel, pois não se faz notar por produtos próprios, mas nas maneiras de empregar os produtos impostos por uma ordem econômica dominante. (CERTEAU, 2012, p. 39, grifos do autor).

Essa produção sociocultural espetacularizada, inclusa a científica, parte de pressupostos relacionados às estratégias que a realizam, produzindo visibilidades dos seus efeitos sobre os consumidores, ao mesmo tempo que invisibiliza as práticas desses sujeitos nos cotidianos, gerando a marginalidade de uma maioria, uma marginalidade de massa, ao considerar "[...] a atividade cultural dos não produtores de cultura, uma atividade não assinada, não legivel [...]" (CERTEAU, 2012, p. 43), submissa, passiva frente à produção hegemônica e suas redes de vigilância e reprodução. Assim, nos questionamos:

Se é verdade que por toda a parte se estende e se precisa a rede da 'vigilância', mais urgente ainda é descobrir como é que uma sociedade inteira não se reduz a ela: que procedimentos populares (também 'minúsculos' e cotidianos) jogam com os mecanismos da disciplina e não se conformam com ela a não ser para alterá-los; enfim, que 'maneiras de fazer' formam a contrapartida, do lado dos consumidores (ou dos 'dominados'?), dos processos mudos que organizam a ordenação sócio-política. (CERTEAU, 2012, p. 40-41)

Certeau observa que os consumidores realizam usos diferenciados da produção sociocultural hegemônica, subvertem suas estratégias com "maneiras de fazer", que "constituem as mil práticas pelas quais os usuários se apropriam do espaço organizado pelas técnicas da produção sociocultural" (CERTEAU, 2012, p. 41). Salienta o autor, que as práticas dos consumidores são marcadas por táticas de apropriação e bricolagem dos produtos disponibilizados e das ações realizadas pelos produtores, identificadas como estratégias:
[...] o cálculo das relações de força que se torna possivel a partir do momento em que um sujeito de querer e poder é isolável de um 'ambiente'. Ela postula um lugar capaz de ser circunscrito como próprio e portanto capaz de servir de base a uma gestão de suas relações com uma exterioridade distinta. A nacionalidade política, econômica ou científica foi construída segundo esse modelo estratégico. (CERTEAU, 2012, p. 45)

As estratégias compõem o conjunto dos fazeres-poderes-conhecimentos engendrados por sujeitos de poder (empresas, organizações, governos etc.), que se instituem/impõem, por meio de uma produção (econômica, política e cultural) que se faz hegemônica, e busca constantemente agenciar-submeter-controlar os consumidores, através de seus produtos. 0 currículo oficial, documento prescritivo, regulador (SACRISTÁN, 2013), e os conhecimentos científicos que o compõem são um exemplo dessa produção.

Por outro lado, Certeau ressalta que os consumidores realizam outra produção, chamada de consumo, que não se faz visível devido à predominância das estratégias. Uma produção que se realiza por meio de táticas, do conjunto dos fazeres-saberes-poderes invisibilizados numa sociedade porque "não pode contar com um próprio, nem portanto com uma fronteira que distingue o outro como totalidade visivel" (CERTEAU, 2012, p. 45). As táticas ocorrem pelas maneiras como os consumidores usam astuciosamente a produção sociocultural hegemônica em proveito próprio, como se insinuam no tempo e nos acontecimentos, aproveitando-se dos lances e das ocasiões para dar golpes, "vigiando para 'captar no voo' possibilidades de ganho". Por meio das táticas do consumo, incessantemente "o fraco deve tirar partido de forças que the são estranhas" (CERTEAU, 2012, p. 46).

Dessa maneira, inverter a análise da ação educativa, partindo do meio, de dentro do currículo realizadopensado nas práticas que 
se desenvolvem nos cotidianos de escolas públicas, em vez da posição superior, da ótica dos que produzem as estratégias e tentam determinar a realidade, significa uma tentativa de produzir visibilidades sobre "os modos de proceder da criatividade cotidiana", sobre a produção "microbiana", "astuciosa", "silenciosa" e "quase invisivel" dos consumidores, estudantes e professores, que vivenciam tais cotidianos, geralmente vistos como espaços de imposição política e reprodução das desigualdades sociais, lugar de problemas/negatividade. Nesse sentido, entendemos os cotidianos como "espaçotempo rico em criações, reinvenções e ações, recusando a noção hegemônica segundo a qual o cotidiano é espaçotempo de repetição e mesmice" (OLIVEIRA, 2012, p. 51).

Com Certeau (2012) e estudiosos brasileiros do currículo e sua produção nos/dos/com os cotidianos escolares (ALVES et al., 2012; OLIVEIRA, 2012; FERRAÇO; CARVALHO, 2012, entre outros), nos propomos a colocar luzes sobre as "maneiras de fazer" e realizar o currículo nas práticas coletivas que ocorrem nesses cotidianos, práticas de construção de conhecimentossaberes que envolvem negociação-produção de sentidos/pensamentos e de subjetividades, desenvolvidas entre professores, estudantes e demais sujeitos que ali se encontram. Assim, apostando em suas potencialidades criativas, expressamos nossa crença no fato de que "as táticas do consumo, engenhosidade do fraco para tirar partido do forte, vão desembocar em uma politização das práticas cotidianas" (CERTEAU, 2012, p. 44).

Dentre as tantas perspectivas disponiveis para se pensar o currículo escolar, optamos por uma noção que o considera como um conjunto imensurável de trajetórias/percursos realizadospensados pelos sujeitos nos espaçostempos escolares, marcados tanto pelo currículo prescritivo, pelos conhecimentos científicos e relações de poder, estabelecidas no campo das estratégias, quanto pelas práticas que penetram a escola através dos estudantes, dos professores e demais sujeitos que nela habitam, hibridizando-se por meio de táticas e bricolagens, que instauram uma diferença e compõem um currículo singular, inventado, praticadopensado coletivamente. Nessa perspectiva, queremos questionar como os sujeitos, imbricados nos cotidianos de escolas públicas e atravessados pelas condições-determinações-concepções que lhes são oferecidas-impostas (ao consumo), empreendem usos-apropriações e bricolagens que configuram táticas-invenções coletivas de construção e expressão de conhecimentos e de criação-desenvolvimento de currículos (ALMEIDA, 2014).

Assim, empreendemos uma tentativa de deslocar nossa visão e pensamentos do currículo oficial, documento prescritivo, regulador, para o currículo realizado, praticadopensado pelos sujeitos nos/dos/com os cotidianos de escolas públicas. Da mesma forma, desviamos nossa análise sobre o currículo e as práticas que se desenvolvem em torno da sua realização, do campo das estratégias para o das táticas, da perspectiva dos produtores para a dos consumidores, da macro para a micropolítica, das hostes dos poderes instituídos e disseminados massivamente para a invisibilizada (e muitas vezes distorcida por quem olha de cima ou de fora) produção microbiana (e os micropoderes que a envolvem).

Essa produção microbiana é realizada nas práticas dos sujeitos ordinários que habitam os cotidianos escolares, a quem foi reservado apenas o lugar do consumo, da execução das macropolíticas de educação e currículo, da transmissão de conhecimentos e, muitas vezes, da culpabilização por resultados verificados-produzidos através de questionáveis sistemas de avaliação, externos, massivos e homogeneizantes, que não consideram os pro- 
cessos vividos/experimentados nos cotidianos escolares, tão pouco as condições concretas em que tais práticas são desenvolvidas.

Colocadas essas questões, podemos direcionar nossa reflexão mais concretamente para a produção do currículo nos cotidianos de escolas públicas do Ensino Médio, considerando os contextos e as transformações ocorridas nas últimas décadas, bem como os processos de apropriação que os sujeitos, imersos nesses espaçostempos, empreendem na realização de suas práticas.

\section{Transformações sociotécnicas, estratégias e táticas no currículo do Ensino Médio}

Diversas transformações sociopolíticas, econômicas e culturais, associadas ao desenvolvimento sociotécnico têm ocorrido nas últimas décadas do século XX e início do atual, especialmente no campo da informática, das tecnologias de informação e comunicação (TIC), das mídias digitais, cada vez mais integradas aos mais diversos dispositivos eletrônicos (computadores, notebooks, tabletes, celulares, câmeras etc.) e suas interconexões em redes de compartilhamento de informações, imagens, sons e conhecimentos-saberes.

Essas mudanças vêm afetando um número cada vez maior de pessoas ${ }^{3}$ e têm contribuído para alterar seus modos de pensar-agir-sentir-aprender-criar nos cotidianos (CERTEAU, 2012), vividos em quase todos os espaçostem-

3 No município de Ichu, com cerca de seis mil habitantes, onde se situa o Colégio Estadual Aristides Cedraz de Oliveira (CEACO), escola de Ensino Médio em que realizamos a pesquisa de mestrado, cujos resultados são usados para ilustrar as reflexões desenvolvidas neste trabalho, a maioria dos jovens (estudantes) possui algum tipo de acesso à internet: através de dados móveis, em casa ou na casa de parentes/amigos, em alguns locais públicos, como bares e, especialmente, na escola em que estudam, que dispõe de rede wi-fi. Tanto na área urbana quanto na rural existem serviços de internet, cobrindo praticamente todo o território do município. pos contemporâneos, desafiando a escola, assim como as demais instituições sociais imersas nesse fluxo, a reorganizar suas práticas, repensar os sentidos da sua ação educativa e dos currículos praticadospensados (OLIVEIRA, 2012).

O desenvolvimento tecnológico em curso tem desencadeado um intenso, incontrolável e hibridizado fluxo de informações, dados e conhecimentos-saberes, codificados e compartilhados através de redes digitais, em forma de textos, sons e imagens (fotografias e vídeos), impactando significativamente os cotidianos vividos pelas pessoas e provocando alterações nas maneiras de pensar, conhecer, existir e agir no mundo. A integração tecnológica e a criação de “[...] redes interativas de computadores estão crescendo exponencialmente, criando novas formas e canais de comunicação, moldando a vida e ao mesmo tempo, sendo moldadas por ela" (Castells, 1999, p. 40). Nesse mesmo sentido, Pierre Lévy (2007, p. 22) considera que "é impossivel separar o humano de seu ambiente material, assim como dos signos e das imagens por meio das quais ele atribui sentido à vida e ao mundo", reforçando a ideia de que estamos vivendo uma revolução sociocultural.

Cada vez mais, as pessoas têm se organizado em diversas comunidades virtuais (que extrapolam os laços e limites geográficos das comunidades tradicionais ou locais), articuladas através de redes sociodigitais. Por meio delas e com a utilização de diversos dispositivos, inúmeros softwares, interfaces, ferramentas digitais, pessoas de diferentes lugares, culturas, pensamentos, convicções, faixa etária etc., produzem e compartilham conhecimentos-saberes, informações e as próprias vivências no mundo, por meio de uma multiplicidade de formatos e mídias-linguagens digitais (textos, imagens, sons, vídeos). Essas redes, engendradas de maneira rizomática, hipertextual e hipermidiática, compõem o que Lévy (2007) des- 
creve como ciberespaço, uma nova forma de organização cultural, a cibercultura.

Redes cujo funcionamento, segundo Lima Jr. (2005, p. 17), pode ser visto "como metáfora inspiradora ou arquétipo de um novo pensar/ agir na prática pedagógica, especialmente na práxis curricular". Nesse sentido, as atuais tecnologias de comunicação "representam não só um conjunto de ferramentas e métodos de funcionamento, mas uma composição simbólica que atua no desejo e na subjetividade" (LIMA JR., 2005, p. 18).

Esse complexo contexto sociocultural envolve, especialmente, os jovens, estudantes do Ensino Médio, que se mostram mais abertos e ávidos às inovações tecnológicas e às mudanças culturais, mesmo que, às vezes, sem a devida consciência dos processos históricos em que estão inseridos. Assim, Nova e Alves (2011, p. 123) observam que os jovens são:

[...] sujeitos que interagem com o mundo a partir da mediação de tecnologias (TV, videogames e computadores) e que tem nas imagens e nos sons (cada vez mais hibridizados) a base dos processos comunicativos e cognitivos [...] organizando sua existência a partir não apenas da lógica da escrita e da linearidade, mas por meio de pensamentos hipertextuais e associativos.

Desse modo, notamos, nos cotidianos de escolas do Ensino Médio, a penetração de dispositivos tecnológicos, especialmente do celular, artefato que, atualmente, possibilita uma constante conexão à internet e a produçãocompartilhamento-consumo de mensagens e imagens sobre os mais diversos aspectos $\mathrm{e}$ momentos da vida cotidiana dos sujeitos (especialmente os jovens-estudantes, mas também de professores, gestores e demais funcionários) que habitam esses espaçostempos escolares.

Muitas vezes incômoda e conflituosa, ${ }^{4}$ essa

4 Muitos professores questionam o uso do celular em sala de aula, como aparato que atrapalha a aula, dispersa a atenção dos alunos; algumas escolas têm cria- “in-vasão" dos dispositivos na vida dos sujeitos nos cotidianos da escola, como em outros espaços sociais, tem provocado muitas discussões e reflexões a respeito de seus usos, considerando que as tecnologias são dispositivos criados pelo homem para melhorar sua ação no mundo, mas cuja utilização é simultaneamente instituída pelo homem e instituinte da sua própria existência, de determinados tipos de subjetividade, de modos de ser-pensar-agir forjados na interação sujeitos-tecnologiasmundo.

Esse contexto de transformações socioculturais e tecnológicas, muitas vezes marcadas por tensões produzidas em função de interesses mercadológicos, desencadeou transformações no campo da política educacional brasileira, principalmente a partir da aprovação da Lei de Diretrizes e Bases da Educação - LDB 9.394/96. Mais especificamente sobre o currículo do Ensino Médio, foram criadas e reformuladas as Diretrizes Curriculares Nacionais do Ensino Médio - DCNEM. ${ }^{5}$ Além disso, foi criado o Programa Nacional de Informática na Educação - Prolnfo, ${ }^{6}$ reformulado pelo Decreto $76.300 / 2007$, ampliando as estratégias de distribuição de computadores nas escolas públicas brasileiras, para uma política de inserção de Tecnologias da Informação e Comunicação (TIC).

Essas e outras legislações/políticas educacionais desenvolvidas no Brasil, após a aprovação da Constituição de 1988, vêm constituindo um conjunto de estratégias de governo,

do normas específicas para disciplinar seu uso e até proibi-lo; pais questionam o tempo que as crianças e jovens dedicam ao uso desses dispositivos tecnológicos; a disponibilização de rede wi-fi nas escolas tem sido objeto de divergência entre professores e alunos, mesmo que ambos não abram mão do uso cotidiano da internet etc.

5 Resoluções 03/1998 e 02/2012 da Câmara de Educação Básica do Conselho Nacional de Educação.

6 Através da Portaria 522, de 09 de abril de 1997.

7 Decreto que alterou a denominação do Programa Nacional de Informática na Educação para Programa Nacional de Tecnologia Educacional. 
de agenciamento/disciplinamento (FOUCAULT, 2004) do currículo e das práticas no Ensino Médio oferecido em escolas públicas. Tais políticas desencadeiam táticas de apropriação e bricolagem (CERTEAU, 2012), realizadas por estudantes, professores e demais sujeitos, praticantespensantes, que compõem redes de conhecimento e de produção de currículos (FERRAÇO; CARVALHO, 2012) nesses cotidianos escolares, pressionados também pelas crescentes demandas sociais por uma educação pública que assegure inserção sociocultural e econômica aos jovens brasileiros, especialmente aos das camadas populares.

Nesse contexto, os educadores e demais sujeitos praticantespensantes da escola, colocaram-se diante do desafio de desenvolver práticas que estabeleçam conexões/diálogos com as vivências cotidianas dos estudantes (jovens) e possibilitem a construção coletiva de conhecimentos, o que implica a negociação -produção de sentidos/subjetividades, enfim, a realização de um currículo relacionado às transformações socioculturais vividas na contemporaneidade, marcadas pelo grande desenvolvimento de artefatos, mídias e linguagens (sobretudo, digitais).

Assim, nos últimos dez anos, temos presenciado a inserção de artefatos tecnológicos nas escolas públicas (laboratório de informática, conexão à internet banda-larga, filmadora, câmera digital, TV-pendrive, tablets, projetores multimídia, lousa digital, salas de recursos multifuncionais etc.), bem como de discursos (muitas vezes salvacionistas ou economicistas), discussões e processos de formação, envolvendo professores e gestores, sobre a utilização de mídias, linguagens e dispositivos tecnológicos nos processos de construção de conhecimento, na realização do currículo escolar. Um significativo debate vem sendo realizado nos meios acadêmico-científicos, políticos, econômicos e culturais, frente às trans- formações que estão ocorrendo, ressoando/ atravessando os cotidianos das escolas.

Apesar das precárias condições materiais e financeiras em que se encontram muitas escolas públicas, ainda que tenham melhorado um pouco na última década, acreditamos que a entrada de dispositivos tecnológicos na escola, especialmente das TIC e suas mídias-linguagens - seja pela via das políticas públicas, seja pelas mãos dos próprios estudantes que não se desgrudam de seus celulares - tem movimentado os cotidianos do Ensino Médio e contribuído para alterar os modos de vida, de cognição, bem como as formas de ser-pensar-sentir, as maneiras de construir-criar-compartilhar conhecimentos-saberes, sentidos, subjetividades, informações e imagens no/do mundo, na/da escola e de si mesmos.

Enredados nesses contextos, os sujeitos que habitam os cotidianos escolares são provocados a pensar a utilização das mídias enquanto artefatos culturais que podem potencializar a construção de conhecimentos-saberes, questionando as pedagogias tradicionais, calcadas no paradigma de transmissão-comunicação linear de conteúdos e informações. Professores, estudantes e demais sujeitos que atuam em escolas públicas são desafiados a pensar sobre a potência da utilização de tecnologias sociodigitais na criação de um currículo que proporcione aos estudantes uma maior interatividade (LÉVY, 2007; SILVA, 2011), que possibilite processos coletivos-colaborativos e criativos de construção de conhecimentos e de produção de subjetividades nos contidianos escolares.

Não se trata de usar as tecnologias a qualquer custo, por modismo ou como dispositivo que facilita a transmissão de conhecimentos, mas de compreender-aproveitar a potência criativa desses artefatos, os diferentes usos deles em diversos espaçostempos e as mudanças na maneira de estar-participar no/do mun- 
do, de lidar com o conhecimento, com a informação e, consequentemente, com o poder, questionando "[...] profundamente as formas institucionais, as mentalidades e a cultura dos sistemas educacionais tradicionais e, sobretudo, os papéis de professor e de aluno" (LÉVY, 2007, p. 172).

Nessa mesma direção, Fischer (2007, p. 291) destaca que as mídias estão provocando:

[...] uma profunda alteração nos modos de existência contemporâneos, em que as práticas cotidianas - também da escola, por certo - se transformam, particularmente no que se refere às nossas experiências com os saberes, às trocas com os outros, às formas de inscrevernos no social, de escrever, de falar, de pensar o mundo e a nós mesmos.

Costa (2011, p. 274) também alerta que “a mídia integra dispositivos poderosos com profundas repercussões na reconfiguração de todas as instâncias e dimensões da vida nas sociedades contemporâneas". Assim, realizarpensar processos/situações de produção colaborativa de conhecimentos-saberes e de sentidos/subjetividades nos cotidianos escolares, utilizando os variados dispositivos -linguagens-mídias, apresenta-se como uma possibilidade de questionar a lógica tradicional (transmissão linear, unidirecional, hierarquizada) que tem marcado fortemente as práticas sociais: educativas, comunicativas, políticas etc.

Para Silva (2011, p. 55), "transitamos da transmissão para a interatividade abrindo perspectivas para novos fundamentos em comunicação e educação". As práticas educativas tradicionais, baseadas no modelo comunicacional clássico um-todos (emissormensagem-receptor), estão sendo pressionadas por mudanças, com a emergência de um novo paradigma de comunicação pautado na interação todos-todos: utilizando-se das atuais mídias, "todos" podem produzir-trans- mitir-receber conhecimentos e informações, simultaneamente.

Contudo, é preciso ressaltar que, em virtude das desigualdades socioeconômicas vigentes nas sociedades capitalistas, nem "todos" têm as mesmas condições de acesso a essas mídias, mesmo que sua proliferação tenha favorecido a redução dos custos dos dispositivos e dos serviços de internet, ampliando, cada vez mais, o acesso às camadas populares.

Entretanto, precisamos engendrar relações mais horizontais entre os sujeitos e aguçar a percepção sobre os enredamentos que se tecem em seus fazeres-saberes-poderes, tendo no rizoma e no hipertexto uma metáfora para a produção do currículo nos/com os cotidianos escolares. "Pensar currículos em redes implica pensar o conhecimento e a aprendizagem a partir de agenciamentos coletivos que se produzem em meio à multiplicidade e a processos de relações não hierárquicas inseridas no cotidiano escolar" (FERRAÇO; CARVALHO, 2012, p. 145).

\section{Práticas de construção de conhecimentos, utilização de mídias e invenção no currículo}

Com o intuito de ilustrar nossas discussões, trazemos algumas reflexões, a partir das experimentações realizadas no Colégio Estadual Aristides Cedraz de Oliveira (CEACO), em Ichu/BA, escola de Ensino Médio em que realizamos uma pesquisa de mestrado, ${ }^{8}$ que investigou o Projeto Comunicação, Interação e Aprendizagem. ${ }^{9}$

8 Pesquisa de mestrado, cujos dados foram produzidos através de oficinas de produção de vídeo-narrativas, em que um grupo de 12 estudantes criou vídeos para expressar sua experiência com o Projeto Comunicação, Interação e Aprendizagem.

9 No Projeto de Comunicação (como é conhecido na escola), os estudantes do 2 o ano produzem notícias, entrevistas, imagens e programas radiofônicos sobre atividades/assuntos/acontecimentos ocorridos-relacionados nos/aos cotidianos da escola, utilizando mídias e conhecimentos referentes às três atividades -linguagens utilizadas/desenvolvidas: rádio-escola, 
Partindo das vídeo-narrativas produzidas pelos estudantes na pesquisa, percebemos que eles consideram significativas e prazerosas as experiências vividas através das produções - publicações de informações realizadas por meio das atividades/situações comunicativas experimentadas no Projeto de Comunicação, provocando efeitos-sensações-afecções nas pessoas envolvidas nos cotidianos do CEACO. São processos de construção de conhecimento que ocorrem por meio de experimentações, pela utilização tateante de mídias e linguagens através das quais os estudantes produzem e veiculam seus textos, orais e escritos, dentrofora da escola.

Assim, os estudantes são desafiados a produzir e publicar informações em cotidianos vividos, situações concretas de uso dos gêneros textuais, linguagens e mídias nos cotidianos do CEACO, afetando as pessoas neles envolvidas com sua voz-texto-imagens e maneiras de pensar-entender-expressar os acontecimentos e vivências nesses cotidianos. São atividades que possibilitam a produção-veiculação das expressões dos estudantes e que não visam, como acontece geralmente nas disciplinas escolares, a repetição/ reprodução de conhecimentos, em atividades cujo objetivo é verificar/determinar o que/ quanto os alunos aprenderam do que lhes foi ensinado. Ocorre uma produção/utilização textual destinada aos leitores/ouvintes que habitam os cotidianos da escola e às pessoas da comunidade externa, diferente do que geralmente acontece com outras produções realizadas na escola, apenas lidas/ouvidas/ avaliadas pelo professor.

No vídeo "Comunicação: futuro presente",

blog (Disponível em: <http://ceacoichu.blogspot.com. br>) e boletim impresso.

10 Vídeo produzido pelos estudantes envolvidos durante a pesquisa de mestrado descrita na nota 8. Disponível em: <https://drive.google.com/open?id=0B2c3LtYjCxaad1pmWk5iTF84S0U\&authuser $=0>$. Acesso em: 08 ago. 2017. produzido coletivamente no segundo ciclo de oficinas da pesquisa, com um tom enfático, o estudante Jociel ${ }^{11}$ narrou que:

com o Projeto a gente aprende e vê coisas que a gente nem imagina. A gente chega a estudar no primeiro ano, a gente não imagina fazer uma apresentação de rádio, ser locutor... Aí, com esse Projeto, eu acho que muitos alunos saíram daqui inspirados em relação com a comunicação e através desse Projeto eu vejo a vida de forma diferente. (JOCIEL, vídeo Comunicação: futuro-presente, 2013)

No Projeto "o estudante tem o acesso aos meios de comunicação e passa a ter noção de como funciona o processo pelo qual a notícia faz antes de chegar até a mídia" (LAYS, vídeo $E$, 2012). São conhecimentos que se configuram como uma noção sobre o processo de produção-veiculação de informação, uma experiência/experimentação com as mídias e as linguagens envolvidas, que possibilitam a expressão de pensamentos nos/sobre os cotidianos escolares e fora deles, como acontece no boletim "CEACO Informa" e no blog "CEACO".

[...] Eu aprendi a fazer notícias, reportagens... e eu gostei muito. [...] A gente tem que trabalhar em cima daquilo [...] pra transmitir aquilo para outras pessoas que não teve a oportunidade de ver no momento. Eu acho que é uma diferença enorme! A gente aprende mais! (TATIANE, vídeo Comunicação: futuro-presente, 2013)

A estudante Tatiane comenta as experiências expressivas vividas por ela, ressaltando como esse processo de construção de conhecimentos em cotidianos vividos é diferente e mais significativo do que outros comumente realizados na escola.

11 Os estudantes participantes da pesquisa foram identificados ao longo do texto com o seu primeiro nome, uma maneira que encontramos para valorizar sua participação e expressar o processo coletivo/colaborativo de produção do texto-pesquisa. Vale lembrar que obtivemos todos os consentimentos legais dos sujeitos envolvidos para a publicação de suas narrativas, dos vídeos produzidos e de suas próprias imagens. 
Essas narrativas parecem indicar que a produção-publicação de textos em cotidianos vividos, destinados a diversos leitores dentrofora da escola, provoca uma preocupação com a necessidade de escrever de maneira que sejam compreendidos por quem tem acesso a eles. Não é, portanto, uma preocupação com uma leitura avaliativa a ser feita somente pela professora, como geralmente ocorre nas atividades escolares, mas, provavelmente, por serem produções que serão lidas pela comunidade escolar e externa, possibilitam aos estudantes uma aprendizagem efetiva, uma apropriação dos recursos linguísticos inerentes à escrita e aos gêneros utilizados/desenvolvidos.

Bastante... produção de texto, produção de notícias que eu não sabia nem pra onde ia, como mexer em computador... Muita coisa mudou! Porque a pessoa se desenvolve mais... naquilo que ela faz. Até na fala, em termos da rádio, se desenvolve bem mais. O meu caso foi esse: Eu desenvolvi em tudo! (REIGIANE, vídeo Comunicação: futuro-presente, 2013)

O processo de produção de textos para o boletim e o blog possibilita a construção de conhecimentos a respeito da atividade busca/registro de informações, por meio da participação dos estudantes na cobertura de eventos e/ou acontecimentos da escola, desempenhando o "papel de repórter": fazer anotações, produzir fotografias, realizar entrevistas ou registrar opiniões de participantes e/ou organizadores, coletar material como folders ou roteiro de atividades etc. De posse dos registros da cobertura dos acontecimentos, os estudantes selecionam imagens, escrevem, revisam e digitam-formatam os textos a serem publicados no boletim e no blog; assumindo ainda a tarefa de distribuição do impresso na comunidade escolar e externa. Esse processo também possibilita a construção de conhecimentos-saberes e apropriações relacionadas às mídias digitais: softwares-aplicativos, ferramentas de edição de texto-imagens e postagem/publicação no blog e no Facebook.

Contudo, os estudantes destacam a rádio -escola e a produção de textos/expressões orais, considerando-as como as experiências mais marcantes vividas no Projeto de Comunicação. "Eu vi que a rádio é um meio de comunicação muito desenvolvido. Com a rádio, a gente aprende muito, perde mais a timidez, fala mais, se comunica mais... melhor" (JOCIEL, vídeo $G, 2012$ ). Nos vídeos e nas oficinas surgem-aparecem muitas narrativas sobre a rádio-escola e imagens do espaço onde ela se desenvolve e dos equipamentos utilizados, a realização ou simulação de programas radiofônicos, o que nos indica a importância que os estudantes atribuem a essa atividade/linguagem, experiências que proporcionam a construção de conhecimentos-saberes significativos para suas vidas.

No vídeo em que foram capturadas as imagens a seguir (figura 1), é possivel notar como o apresentador e a entrevistada utilizam variadas táticas enunciativas (CERTEAU, 2012) e transitam/deslizam habilmente pela linguagem radiofônica: espontaneidade diante da câmera e nas expressões; intensa interlocução apresentador-entrevistada-ouvintes (o apresentador e a entrevistada incorporam, nas expressões, todo o cenário/contexto do programa "Conexão colegial"); carga de emoções/sentimentos inseridos nos discursos/ mensagens, expressando afetos para com as questões abordadas; constante tentativa de envolver o ouvinte pela imaginação, provocando-o a desencadear imagens e a compor o cenário de expressão que possibilita a compreensão e a interação com o texto/discurso radiofônico. 
Figura 1 - Simulação de entrevista na rádio-escola, apresentada no vídeo "Conexão Colegial".

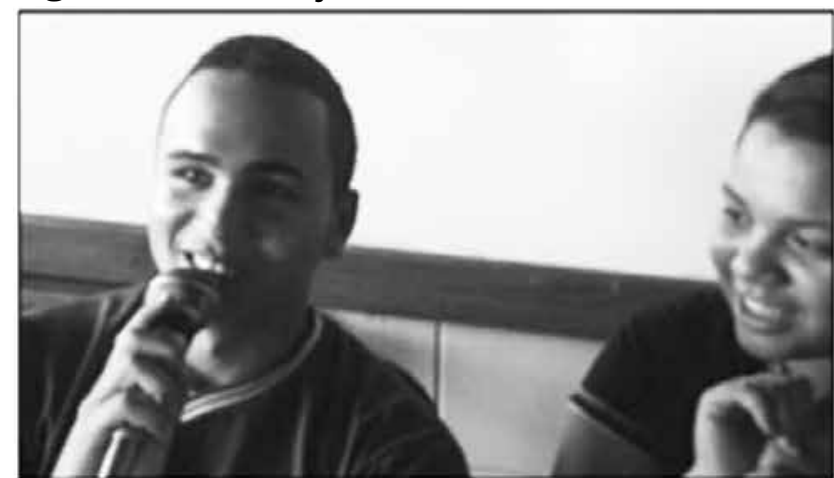

Fotograma: Vídeo “Conexão Colegial”,12 2012.

Nos contextos das atividades-linguagens desenvolvidas no Projeto, as performances realizadas pelos estudantes ocorrem através dos usos que fazem, em suas práticas comunicativas, dos recursos linguísticos e midiáticos disponiveis em cada uma delas.

Outras duas questões (interdependentes), que se destacam nos processos de construção de conhecimentos ocorridos no Projeto de Comunicação, sobretudo na rádio-escola, dizem respeito à autonomia e à troca de experiências entre os estudantes.

A própria rádio... lembrem aí como é que funcionava! Eu dava uma aula inicial... [...] as outras, o que é que eu fazia? Eu ia lá pra rádio ensinar vocês como é que usava? Dificilmente eu ia pra lá ensinar vocês como é que usava. [...] Um colega que tinha mais experiência ia lá e ajudava vocês na rádio. E vocês se viravam. (HUDA, professora-coordenadora do Projeto, oficina $14 / 11 / 2013$ )

Os processos colaborativos de construção de conhecimentos e saberes foram bastante discutidos/narrados nas oficinas e nos vídeos. Isso talvez porque essas práticas escapam às formas tradicionais por meio das quais, geralmente, se organizam as atividades escolares, pelo fato dos estudantes, autonomamente, produzirem e publicarem textos (orais e escri-

12 Disponivel em: <https://drive.google.com/open?i$\mathrm{d}=0 \mathrm{~B} 2 \mathrm{c} 3 \mathrm{LtYj}$ jCxaaZGZBQLIPWWp5bWM \&authuser=0>.

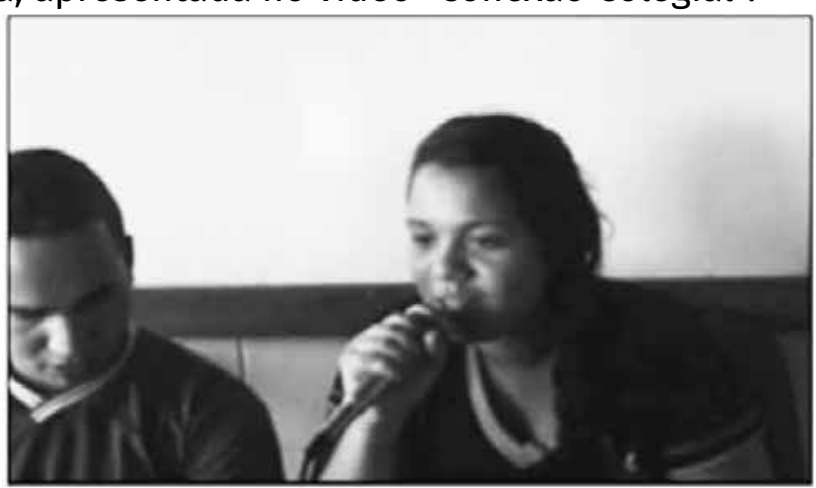

tos), enquanto práticas expressivas que afetam a si mesmos e aos demais estudantes e pessoas nos cotidianos escolares. São textos que provocam os interlocutores e desencadeiam uma produção coletiva de sentidos.

Figura 2 - Troca de experiências na operação dos equipamentos da rádio-escola.

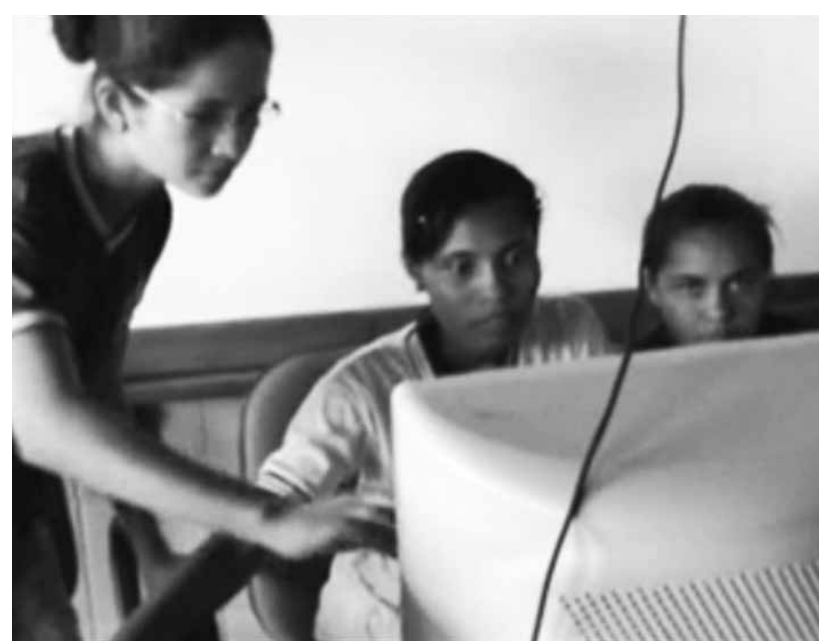

Fotograma: Vídeo “Jovem em talento"13 2012.

Como é possivel observar na sequência de fotografias, a seguir, Wadson e Reigiane tateiam tentando ajustar o microfone para que possam entrar no ar. São três tentativas realizadas por Wadson (estudante cego) sem sucesso, o que faz Reigiane ficar desorientada, mas quando Wadson consegue abrir o volume do microfone, eles riem satisfeitos.

13 Disponivel em: <https://drive.google.com/open?i$\mathrm{d}=0 \mathrm{~B} 2 \mathrm{c} 3 \mathrm{LtY}$ jCxaaWUdaY0Nrb2UyZTA\&authuser=0>. 
Figura 3 - Wadson e Reigiane tateiam na operação dos equipamentos.

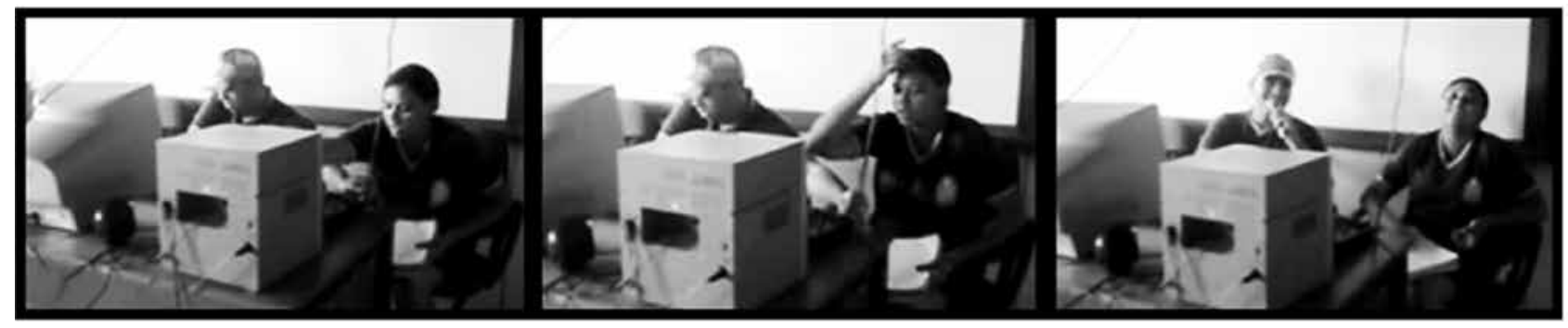

Fotogramas: Vídeo “Interação jovem", 2012.

Alguns vídeos mostram como os estudantes vão tateando, experimentando, por meio de tentativas e erros, de interações e colaboração, os usos das mídias e linguagens no Projeto. Por meio do contato com essas mídias, os estudantes vão se apropriando delas, enquanto ferramenta de produção/realização de práticas comunicativas concretas, nos cotidianos da escola, realizando usos que objetivam a produção de textos/narrativas a serem publicados, compartilhados com as demais pessoas.

As práticas de construção de conhecimento realizadas-experimentadas pelos estudantes e a professora-coordenadora, no Projeto de Comunicação, constituem uma criação, a invenção de um currículo diferente/singular nos cotidianos do Ensino Médio, que destoa da mesmice geralmente encontrada/visibilizada nos cotidianos de escolas públicas. Um currículo praticadopensado que se materializa na expressão de ideias e pensamentos, que encontra eco/sentido na vida dos estudantes dentrofora da escola, em vez da costumeira e desinteressante reprodução/repetição de conhecimentos que aí geralmente se observa.

É totalmente diferente das outras matérias! Porque as outras matérias tá preocupada com o resultado, tá preocupada com a nota. E aqui, a gente tá preocupado [...] como se fosse nosso trabalho, tá preocupado com o resultado lá fora. Com o que é que os funcionários, os alunos tão achando do que a gente tá fazendo, né?

14 Disponível em: <https://drive.google.com/open?i$\mathrm{d}=0 \mathrm{~B} 2 \mathrm{c3LtYj}$ CxaaY1M4NFk4dXd5YkE\&authuser=0>.
Porque a partir do resultado, do que eles estão achando, a gente pode sentir amor por aquilo e levar isso pro resto da nossa vida. (CÍNTIA, vídeo Comunicação: futuro-presente, 2013)

As questões apontadas, no vídeo, pela estudante Cíntia desencadearam muitas discussões, na última oficina, em que os estudantes questionavam o currículo escolar e sua falta de sentido. "Nas matérias é [...] muita teoria, [...] é muita coisa que ninguém usa mais" (MIRLI, oficina 19/11/2013). Buscando compreender a questão, recorremos à noção de conhecimento em rede que introduz um novo referencial nas práticas sociais, considerando que nelas os conhecimentos são tecidos por meio das variadas interações entre os sujeitos que as realizam. Concordamos com:

[...] a inversão da polarização moderna entre teoria e prática, passando-se a compreender o espaço prático como aquele em que a teoria é tecida. Tal proposição, ao reconceituar a prática como o espaço cotidiano no qual o saber é criado, elimina as fronteiras entre ciência e senso comum, entre conhecimento válido e conhecimento cotidiano. (LOPES; MACEDO, 2002, p. 37)

Nesse sentido, recorremos também ao que afirmam Ferraço e Carvalho (2012) sobre a necessidade de pensarmos currículos em redes, realizando processos de construção de conhecimentos, a partir de agenciamentos coletivos, de relações de colaboração e de compartilhamento de saberespoderes, de relações não/ menos hierárquicas.

Desse modo, consideramos que a investigação do processo de produção colaborativa 
e criativa de conhecimentos e criação de currículo é expressão de uma crença-aposta nos “[...] possiveis que se tecem nas redes de conhecimentos dos sujeitos praticantes dos cotidianos" (FERRAÇO; CARVALHO, 2012, p. 159), pautada na poética de um futuro como devir e nas possibilidades da ação coletiva. Percebemos que as práticasteorias realizadas no Projeto de Comunicação constituem uma invenção carregada de singularidades, operada coletivamente, a partir das necessidades/ desejos das pessoas na escola, colocando os estudantes como protagonistas de uma produção que movimenta seus cotidianos e altera seus modos de realizarpensar construção de conhecimentos, currículo, sujeitos e cotidianos escolares.

\section{Considerações e devires}

Com uma produção hibridizada de textos-imagens-sons, os estudantes fazem escolhas-interpretações-recortes-colagens nos/dos/com os cotidianos, inventam maneiras de verpensaragir no mundo, a partir das concepções/ visões que os atravessam cotidianamente. Visões/concepções e textos/vozes/imagens/ sons compartilhados nas vivências cotidianas em que se realizam as atividades do Projeto de Comunicação e que ressoam como possibilidades de construção de conhecimentos e

\section{Referências}

ALMEIDA, Edivan Carneiro de. Construção de conhecimentos e currículos in-venta-dos com as mídias nos cotidianos de uma escola pública de ensino médio. 2014. 144 f. Dissertação (Mestrado em Educação) - Programa de Pós-Graduação em Educação, Universidade Estadual de Feira de Santana, Feira de Santana, 2014.

ALVES, Nilda et al. Como e até onde é possivel pensar diferente? Micropolíticas de currículo, poéticas, cotidianos e escola. Revista Teias, v. 13, n. 27, p. 4966, jan./abr. 2012. Disponivel em: <http:// www.e-pu- criação de currículo, de produção de visibilidades sobre o que criam os sujeitos em suas praticasteorias, nos cotidianos de escolas públicas. Práticas e cotidianos geralmente ofuscados pela produção hegemônica de imagens negativas sobre eles, realizada pelas mídias tradicionais e pela produção de conhecimentos científicos.

São cotidianos e práticas de sujeitos que demandam investigação e a produção de outras visualidades, que provocam fissuras nas imagens/concepções tradicionais de currículo, que possibilitam a percepção da criatividade e invenção de um currículo singular, compartilhado, cheio de vida, alegre, animado e arejado com os significados produzidos pelos estudantes do Ensino Médio.

Tantas são as possibilidades de se realizarpensar a produção de conhecimentos científicos nos/dos/com os cotidianos escolares, na atualidade, quanto as imensuráveis maneiras em que neles se processa a criatividade humana. Desejamos compreender-cartografar-visibilizar os entrelaces que aí se produzem, ao realizar práticas não autorizadas, lançando mão dos artefatos culturais de que dispomos para potencializar a expressão, a invenção e a transformação do mundo em que vivemos, noutro mais igualitário, democrático, cheio de vida e de possibilidades para (re)in-ventá-lo, sempre...

blicacoes.uerj.br/index.php/revistateias/article/ view/24251>. Acesso em: 03 ago. 2017.

BRASIL, Ministério da Educação. Lei no 9.394 de 20 de dezembro de 1996. In: Parâmetros Curriculares Nacionais do Ensino Médio: bases legais. Brasília: Ministério da Educação/Secretaria de Educação Média e Tecnológica, 1999.

BRASIL, Ministério da Educação. Diretrizes Curriculares Nacionais do Ensino Médio. Resolução CNE/ CEB no 3/1998. Disponivel em: <http://portal.mec. 
gov.br/cne/arquivos/pdf/rceb03 98.pdf>. Acesso em: 10 ago. 2017.

BRASIL. Ministério da Educação. Diretrizes Curriculares Nacionais para o Ensino Médio. Resolução CNE/CEB no 2/2012. Disponível em: <http://pactoensinomedio.mec.gov.br/images/pdf/resolucao_ ceb_002_30012012.pdf>. Acesso em: 10 ago. 2017.

BRASIL, Ministério da Educação. Prolnfo. Disponível em: <http://portal.mec.gov.br/index. php?option=com_content \&view $=$ article $\&$ id $=236 \&$ Ite $\mathrm{mid}=471>$ Acesso em: 09 ago. 2017.

CASTELLS, Manuel. A Sociedade em Rede. Tradução de Roneide Venancio Majer. 6. ed. São Paulo: Paz e Terra, 1999.

CERTEAU, Michel de. A invenção do cotidiano: 1. Artes de fazer. Tradução de Ephraim Ferreira Alves. 19. ed. Petrópolis, RJ: Vozes, 2012.

DELEUZE, Gilles; GUATTARI, Félix. Mil platôs: capitalismo e esquizofrenia. NETO, A. G.; COSTA, C. P. (Trad.). vol. 1, Rio de Janeiro: Ed 34, 1995.

COSTA, Marisa Vorraber. Cartografando a gurizada da fronteira: novas subjetividades na escola. In: JUNIOR, D. M. A. et al. (Orgs.). Cartografias de Foucault. 2. ed. Belo Horizonte: Autêntica, 2011. p. 269-294.

FERRAÇO, Carlos Eduardo; CARVALHO, Janete MagaIhães. Lógicas de currículos em redes e projetos. In: FERRAÇO, Carlos Eduardo; CARVALHO, Janete MagaIhães. (Orgs). Curriculos, pesquisas, conhecimentos e produção de subjetividades. Rio de Janeiro: DP et Alii, 2012. p. 143-160.

FISCHER, Rosa Maria Bueno. Mídias, máquinas de imagem e práticas pedagógicas. Revista Brasileira de Educação, v. 12, n. 35, p. 290-299, mai./ago. 2007.

FOUCAULT, Michel. Vigiar e punir. Tradução de Raquel Ramalhete. 29. ed. Petrópolis, RJ: Vozes, 2004.

LÉVY, Pierre. Cibercultura. Tradução de Carlos Irineu da Costa. 2. ed. São Paulo: Editora 34, 2007.

LIMA JR., Arnaud Soares de. Tecnologias inteligentes e educação: currículo hipertextual. Rio de Janeiro: Quartet; Juazeiro, BA: FUNDESF, 2005. p. 13-44.

LOPES, Alice Casemiro; MACEDO, Elisabeth. O pensamento curricular no Brasil. In: LOPES, Alice Casemiro; MACEDO, Elisabeth. (Orgs.). Currículos: debates contemporâneos. São Paulo: Cortez, 2002. p. 13-54.

NOVA, Cristiane; ALVES, Lynn. Estação online: a ciberescrita, as imagens e a EAD. In: SILVA, Marcos. (Org.). Educação online. São Paulo: Loyola, 2011. p. 107-136.

OLIVEIRA, Inês Barbosa de. Currículos e pesquisas com os cotidianos. In: FERRAÇO, Carlos Eduardo; CARVALHO, Janete Magalhães. (Orgs.). Currículos, pesquisas, conhecimentos e produção de subjetividades. Rio de Janeiro: DP et Alii , 2012. p. 47-70.

SACRISTÁN, J. G. (Org.). Saberes e incertezas sobre o currículo. Porto Alegre: Penso, 2013.

SILVA, Marcos. Criar e professorar um curso online: relato de experiência. In: SILVA, Marcos. (Org.). Educação online. São Paulo: Loyola, 2011. p. 53-75.

VEIGA-NETO, Alfredo. Currículo e cultura. Contapontos, Itajaí/SP, ano 2, n. 4, p. 43-50, jan./abr. 2002.

\begin{abstract}
Edivan Carneiro de Almeida é Mestre em Educação pela UEFS - Universidade Estadual de Feira de Santana (2014), Especialista em Educação à Distância (2012) pela UNEB - Universidade do Estado da Bahia / UAB - Universidade Aberta do Brasil, graduado em Pedagogia pela UNEB - Universidade do Estado da Bahia (1999). Participa, como pesquisador colaborador, do grupo de pesquisa TRACE, vinculado ao Programa de Pós-Graduação em Educação da UEFS - Universidade Estadual de Feira de Santana. É professor na Rede Estadual de Educação da Bahia no Colégio Estadual Aristides Cedraz de Oliveira, no município de Ichu/BA. e-mail: edivan.ichu@gmail.com
\end{abstract}

Endereço: Av. Elvira Freitas Ferreira, 824, Centro - Ichu/BA - CEP: 48.725-000; Telefone: 75 98210-1713. 
Elenise Cristina Pires de Andrade é Doutora em Educação pela Universidade Estadual de Campinas e Mestra em Educação pela Universidade Estadual de Campinas. Professora do Departamento de Educação da UEFS (BA) e do Mestrado em Educação, na mesma instituição. É líder, junto com a Profa. Dra. Susana Dias, do grupo de pesquisa multiTÃO: prolifer-artes sub-vertendo ciências e educações\&quot. Participa, na UEFS, do grupo de pesquisa TRACE (Departamento de Educação). Pesquisadora convidada do Grupo OLHO da Faculdade de Educação da Unicamp e pesquisadora associada junto ao Labjor (Unicamp). e-mail: nisebara@gmail.com

Endereço: R. Claudemiro Campos Suzarte, 455, Condomínio Reserva Real, Casa 32 - Bairro SIM - Feira de Santana/BA CEP: 48.725-000; Telefone: 75 99831-7733. 